\title{
Commentary on a Case Study "A Life with and beyond Cancer".
}

\author{
Jan Sitvast*, Guido Bogert and Ingrid Bogert
}

University of Applied Sciences Hogeschool, Utrecht, The Netherlands

Accepted on 27 February, 2017

\section{Commentary}

In this article we argued that patients recovering from cancer can benefit from photographs that tell their story. We used the case of Ann who recovered from breast cancer and demonstrated that being photographed and being able to determine what photographs are made helped the patient to reflect on her life with cancer, but also on her life beyond the disease. We concluded that the photographs mediated the patient's story where otherwise words alone might not have been able to make sense of confused feelings.

Photography facilitates the search for meaning. May-be the core observation in the article was the following:

"Meaning giving is not only a cognitive activity, but much more an expression of vitality, as 'having (again) a mind/fancy for', so being able to enjoy, experience happiness and satisfaction. Remembering and becoming aware of important values in life and pleasant things to do will contribute to more resilience and eventually facilitate the process of recovery from cancer."

This we saw confirmed in other studies as well, for instance in "Cancer Patients' Experiences of Their Personal Strengths through Illness and Recovery" (Rotegard, Fagermoen, Ruland, 2012) where the authors collected data from 26 participants (cancer patients in Norway) in 4 focus group interviews.

Participants in this study described the strengths they used or wished for during illness and recovery. Among them were good mood, mindfulness, willpower, positive relationships, hopes and beliefs, protection, and taking action and control. Patients also reported that healthcare providers rarely focused on patients' strengths, something they fervently wished for. Care providers paying attention to strengths would encourage patients to become active partners in care and feel in control, but may-be of even more importance is that it will nourish the resilience and vitality that patients need to take up their lives again after being recovered. We know from neuro-biological research findings how the body mind, interaction is a complex one and that is an essential connection between bodily experiences and a person's feelings and emotions [1], even to the point that someone's immune system can be conditioned and strengthened [2]. This makes it a crucial factor to focus on vitality and find ways to promote vitality affects, as was done in "A Case Study "A Life with and beyond Cancer" $[3,4]$.

\section{References}

1. Damasio AR. The Feeling of What Happens: Body and Emotion in the Making of Consciousness. New York Times. 1999.

2. Temel JS, Greer JA, Muzikansky A, et al. Early Palliative Care for Patients with Metastatic Non-Small-Cell Lung Cancer. N Engl J Med. 2010;363:733-742.

3. Sitvast J. A Case Study "A Life with and beyond Cancer". J Palliat Care Med. 2016;6: 266.

4. Rotegård AK, Fagermoen MS, Ruland CM. Cancer patients' experiences of their personal strengths through illness and recovery. Cancer Nurs. 2012;35:8-17.

\section{*Correspondence to}

Dr. Jan Sitvast, RN, PhD, MA

Nurse Expert, Lecturer at University of Applied Sciences Hogeschool, Utrecht,

The Netherlands

E-mail: Jan.sitvast@hu.nl 